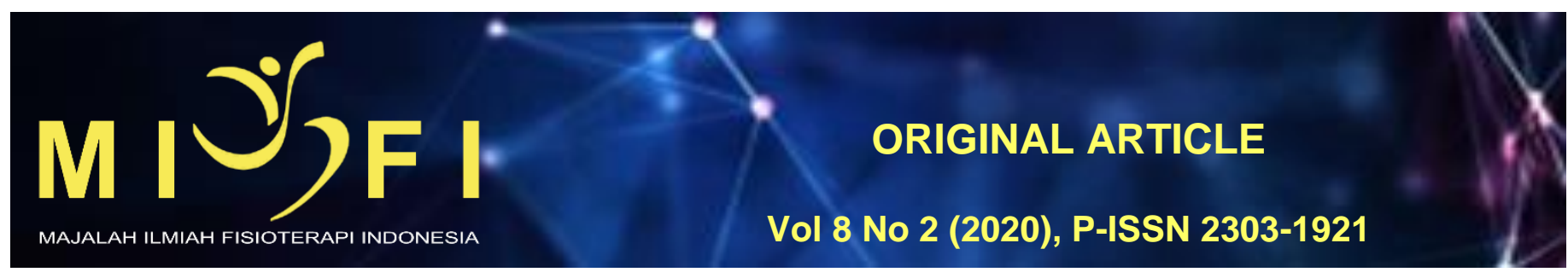

\title{
HUBUNGAN AKTIVITAS FISIK TERHADAP DAYA TAHAN KARDIORESPIRASI DAN TEKANAN DARAH PADA PRIA DEWASA AKHIR DI DENPASAR UTARA
}

\author{
Putu Leli Juniari' ${ }^{1}$ M Widnyana ${ }^{2}$, I Putu Gede Adiatmika ${ }^{3}$, I Made Niko Winaya ${ }^{4}$ \\ ${ }^{1}$ Program Studi Sarjana Fisioterapi dan Profesi Fisioterapi, Fakultas Kedokteran Universitas Udayana \\ ${ }^{2,4}$ Departemen Fisioterapi, Fakultas Kedokteran Universitas Udayana \\ ${ }^{3}$ Departemen IImu Faal, Fakultas Kedokteran Universitas Udayana \\ lely juniari97@yahoo.com
}

\begin{abstract}
ABSTRAK
Aktivitas fisik adalah gerakan tubuh yang dihasilkan oleh otot rangka yang membutuhkan pengeluaran energi saat melakukannya. Data penduduk usia dewasa di Indonesia menunjukkan pada tahun 2011 aktivitas fisik terendah terjadi sebesar 31,9\% pada laki-laki dan 27,9\% pada perempuan dengan total $29,9 \%$ dari keseluruhan penduduk pada tahun 2010.Tujuan dari penelitian ini untuk mengetahui hubungan antara aktivitas fisik terhadap daya tahan kardiorespirasi dan tekanan darah pada pria dewasa akhir di wilayah Puskesmas III Denpasar Utara. Penelitian ini analitik cross sectional yang dilakukan pada bulan April-Mei 2019. Pengambilan sampel dilakukan dengan teknik purposive sampling dan sampel 84 orang pria. Variabel independen penelitian ini yaitu aktivitas fisik diukur dengan kuisioner Physical Activity Questionnaire versi Short-Form (IPAQ-SF). Variabel dependen dalam penelitian ini yaitu daya tahan kardiorespirasi diukur dengan Harvard Step Test dan tekanan darah yang diukur dengan alat stetoskop dan sphygmomanometer. Uji hipotesis yang digunakan yaitu Spearman's Rho Test untuk menilai hubungan aktivitas fisik terhadap daya tahan kardiorespirasi didapatkan hasil $p$ sebesar 0,001 dengan $r$ 0,695 hasil uji dari aktivitas fisik terhadap tekanan darah sistolik didapatkan $p$ sebesar 0,074 dengan $r-0,196$ dan aktivitas fisik terhadap tekanan darah diastolik didapatkan $p$ sebesar 0,848 dengan r 0,021. Berdasarkan hasil penelitian ini disimpulkan bahwa terdapat hubungan yang signifikan antara aktivitas fisik terhadap daya tahan kardiorespirasi, tetapi tidak ada hubungan aktivitas fisik terhadap tekanan darah sistolik dan diastolik pada pria dewasa akhir di wilayah Puskesmas III Denpasar Utara.

Kata Kunci: aktivitas fisik, daya tahan kardiorespirasi, tekanan darah
\end{abstract}

\section{RELATIONSHIP OF PHYSICAL ACTIVITY TO CARDIORESPIRATION AND BLOOD PRESSURE IN END MALE ADULT MEN IN NORTH DENPASAR}

\section{ABSTRACT}

Physical activity is a bodily movement produced by skeletal muscles that require energy expenditure while doing so. Data adult population in Indonesia in 2011 showed the lowest physical activity occurs by $31.9 \%$ in men and $27.9 \%$ in women with a total of $29.9 \%$ of the total population in 2010 . The purpose of this study to determine the relationship between physical activity on cardiorespiratory endurance and blood pressure in adult males end in Puskesmas III North Denpasar. The analytic cross-sectional study conducted in April-May 2019. Sampling was done by purposive sampling techniques and a sample of 84 men. The independent variable of this research that physical activity was measured by a questionnaire Physical Activity Questionnaire version of the Short-Form (IPAQ-SF). The dependent variable in this study is cardiorespiratory endurance was measured by the Harvard Step Test and blood pressure was measured with a stethoscope and sphygmomanometer. Hypothesis test used is Spearman's Rho Test to assess the relationship of physical activity to the durability of cardiorespiratory showed $p$ equal to $0.001 \mathrm{r} 0.695$ test results of physical activity on the systolic blood pressure obtained $p$ equal to 0.074 with $r-0.196$ and physical activity on the diastolic blood pressure is obtained $r p$ equal to 0.848 to 0.021 . Based on the results of this study concluded that there was a significant relationship between physical activity on cardiorespiratory endurance, but no association of physical activity on systolic and diastolic blood pressure in adult males end in Puskesmas III North Denpasar.

Keywords: physical activity, cardiorespiratory endurance, blood pressure 


\section{PENDAHULUAN}

Kemajuan teknologi yang terjadi seiring dengan perkembangan zaman membuat banyak kemudahan yang di rasakan dan secara tidak langsung merubah pola tingkah laku masyarakat. Masyarakat cenderung memilih menggunakan teknologi dalam melakukan pekerjaan mereka. Hal ini disebabkan karena teknologi yang ada menjadikan pekerjaan mereka lebih cepat dan efisien. Sehingga menghasilkan pola hidup masyarakat yang sebelumnya memiliki aktivitas fisik yang aktif menjadi pasif. Tercatat bahwa proporsi aktivitas fisik tergolong kurang aktif secara umum mencapai 26,1 persen di Indonesia. ${ }^{1}$ Berdasarkan data Non-communicable disease country profiles pada tahun 2011 aktivitas fisik terendah di Indonesia terjadi sebesar 31,9\% pada laki-laki dan 27,9\% pada perempuan dengan total $29,9 \%$ dari keseluruhan penduduk pada usia dewasa tahun $2010 .^{2}$

Daya tahan kardiorespirasi merupakan kemampuan jantung, paru, dan pembuluh darah untuk berfungsi secara optimal dalam keadaan istirahat dan latihan untuk mengambil oksigen dan mendistribusikannya ke jaringan yang aktif untuk metabolisme tubuh. ${ }^{3}$ Pengukuran daya tahan kardiorepirasi dalam penelitian ini menggunakan Harvard Step Test dengan validitas dan reabilitas yang cukup tinggi. Tekanan darah merupakan kekuatan yang diperlukan agar dapat mengalirkan darah di pembuluh darah dan beredar mencapai semua jaringan tubuh manusia. Seseorang dengan aktivitas fisik yang kurang memiliki kecenderungan 30-50\% terkena hipertensi daripada mereka yang aktif. Tekanan darah dalam penelitian ini diukur dengan stetoskop dan sphygmomamometer.

Peneliti melakukan observasi pendahuluan dengan mencari data riwayat hipertensi di puskesmas I,II dan III di Denpasar Utara dan peneliti mendapatkan hasil riwayat hipertensi tertinggi pada usia terbilang produktif terjadi pada puskesmas III Denpasar Utara. Berdasarkan data observasi yang sudah ada peneliti menjadikan wilayah puskesmas III Denpasar Utara sebagai subjek penelitian untuk mengetahui hubungan aktifitas fisik terhadap daya tahan kardiorespirasi dan tekanan darah pada pria usia dewasa akhir pada daerah tersebut.

\section{METODE}

Desain penelitian ini menggunakan rancangan analitik dengan pendekatan potong lintang. Penelitian dilakukan pada akhir bulan April sampai awal Mei 2019. Jumlah sampel pada penelitian ini yaitu 84 orang pria. Sampel dipilih menggunakan teknik pengambilan sampel purposive sampling dan memenuhi kriteria inklusi dan eksklusi diantaranya berusia pria dewasa akhir berusia 36-45 tahun, tidak sedang mengalami cedera pada kedua tungkai bawah, tidak memiliki riwayat penyakit sesak nafas dan tidak memiliki riwayat penyakit jantung.

Aktivitas fisik merupakan variabel bebas sedangkan daya tahan kardiorespirasi dan tekanan darah merupakan variabel terikat. Physical Activity Questionnaire versi Short-Form (IPAQ-SF) merupakan kuisioner yang digunakan untuk mengukur aktivitas fisik dengan interpretasi aktivitas fisik ringan ( $<600 \mathrm{METs}-\mathrm{menit} / \mathrm{ming}$ gu), aktivitas fisik sedang (6002.999 METs-menit/minggu), aktivitas fisik tinggi ( $\geq 3.000 \mathrm{METs}-m e n i t / m i n g g u)$. Daya tahan kardiorespirasi diukur dengan menggunakan Hardvard Step Test dengan interprstasi kurang (nilai <50), kategori sedang ( nilai 50-80) dan kategori tinggi (nilai $>80$ ). Tekanan darah diukur dengan alat stetoskop dan sphygmomanometer dengan interpretasi hipertensi stage 2, hipertensi stage 1, pre-hipertensi dan normal terhadap tekanan darah sistolik dan diastolik.

Setelah itu seluruhnya akan dilakukan uji statistik non-parametrik yang digunakan adalah uji Spearman's Rho Test. Tujuannya adalah untuk mengetahui adanya hubungan antara variabel independen yaitu aktivitas fisik dengan variabel dependen yaitu daya tahan kardiorespirasi dan tekanan darah.

\section{HASIL}

Penelitian ini mendata 84 orang pria dewasa akhir dengan rentang usia 36-45 tahun. Berikut adalah tabel analisis data penelitian.

Tabel 1. Distribusi Frekuensi Karakteristik Sampel

\begin{tabular}{lll}
\hline Variabel & Frekuensi (f) & Persentase (\%) \\
\hline Usia & & \\
36 tahun & 10 & 11,9 \\
37 tahun & 7 & 8,3 \\
38 tahun & 8 & 9,5 \\
39 tahun & 6 & 7,1 \\
40 tahun & 16 & 19 \\
41 tahun & 4 & 4,8 \\
42 tahun & 10 & 11,9 \\
43 tahun & 10 & 11,9 \\
44 tahun & 3 & 3,6 \\
45 tahun & 10 & 11,9 \\
Aktivitas Fisik & & \\
Ringan & 25 & 29,8 \\
Sedang & 24 & 28,6 \\
Tinggi & 35 & 41,7 \\
Daya Tahan Kardiorespirasi \\
Kurang & 32 & 38,1 \\
Sedang & 23 & 27,4 \\
Sangat Baik & 29 & 34,5 \\
Tekanan Darah Sistolik & & \\
Normal & 24 & 28,6
\end{tabular}




$\begin{array}{lll}\text { Pre-hipertensi } & 19 & 22,6 \\ \text { Hipertensi I } & 20 & 23,8 \\ \text { Hipertensi II } & 21 & 25 \\ \text { Tekanan Darah Diastolik } & & \\ \text { Normal } & 22 & 26,2 \\ \text { Pre-hipertensi } & 24 & 28,6 \\ \text { Hipertensi I } & 19 & 22,6 \\ \text { Hipertensi II } & 19 & 22,6\end{array}$

Tabel 1 menunjukkan hasil dari distribusi frekuensi karakteristik sampel bahwa dari 84 sampel yang ada terdapat frekuensi pria usia 36 tahun sebanyak 10 orang $(11,9 \%)$, frekuensi pria usia 37 tahun sebanyak 7 orang $(8,3 \%)$, frekuensi pria 38 tahun sebanyak 8 orang $(9,5 \%)$, frekuensi pria usia 39 tahun sebanyak 6 orang $(7,1 \%)$, frekuensi pria usia 40 tahun sebanyak 16 orang $(19,0 \%)$, frekuensi pria 41 tahun sebanyak 4 orang $(4,8 \%)$, frekuensi pria 42 tahun sebanyak 10 orang $(11,9 \%)$, frekuensi pria usia 43 tahun sebanyak 10 orang $(11,9 \%)$, frekuensi pria usia 44 tahun sebanyak 3 orang $(3,6 \%)$ danfrekuensi pria usia 45 tahun sebanyak 10 orang $(11,9 \%)$.

Menunjukkan bahwa dari 84 sampel yang ada terdapat frekuensi pria dengan aktivitas fisik ringan sebanyak 25 orang $(29,8 \%)$, frekuensi pria dengan aktivitas fisik sedang sebanyak 24 orang $(28,6 \%)$ dan frekuensi pria dengan aktivitas fisik tinggi sebanyak 35 orang $(41,7 \%)$.

Hasil juga menunjukkan bahwa dari 84 sampel yang ada terdapat frekuensi pria dengan daya tahan kardiorespirasi kurang sebanyak 32 orang $(38,1 \%)$, frekuensi pria dengan daya tahan kardiorespirasi sedang sebanyak 23 orang $(27,4 \%)$ dan frekuensi pria dengan daya tahan kardiorespirasi sangat baik sebanyak 29 orang $(34,5 \%)$.

Hasil data tekanan darah sistolik menunjukkan bahwa dari 84 sampel yang ada terdapat frekuensi pria dengan tekanan darah sistolik normal sebanyak 24 orang $(28,6 \%)$, frekuensi pria dengan tekanan darah sistolik pre-hipertensi sebanyak 19 orang (22,6\%), frekuensi pria dengan tekanan darah sistolik hipertensi stage 1 sebanyak 20 orang $(23,8 \%)$ dan frekuensi pria dengan tekanan darah sistolik hipertensi stage 2 sebanyak 21 orang $(25,0 \%)$.

Hasil data tekanan darah diastolik menunjukkan bahwa dari 84 sampel yang ada terdapat frekuensi pria dengan tekanan darah diastolik normal sebanyak 22 orang $(26,2 \%)$, frekuensi pria dengan tekanan darah diastolik prehipertensi sebanyak 24 orang (28,6\%), frekuensi pria dengan tekanan darah diastolik hipertensi stage 1 sebanyak 19 orang $(22,6 \%)$ dan frekuensi pria dengan tekanan darah diastolik hipertensi stage 2 sebanyak 19 orang $(22,6 \%)$.

Tabel 2. Uji Normalitas Data

\begin{tabular}{llll}
\hline \multicolumn{1}{c}{ Variabel } & Rerata & Simpang Baku & P \\
\hline Aktivitas Fisik & 2,12 & 0,842 & 0,000 \\
D.T Kardiorespirasi & 1,96 & 0,857 & 0,000 \\
T.D Sistolik & 2,52 & 1,114 & 0,000 \\
T.D Diastolik & 2,42 & 1,111 & 0,000 \\
\hline
\end{tabular}

Tabel 2 menunjukkan dari total responden yaitu 84 orang pria diuji normalitas data sehingga didapatkan nilai signifikansi p (Asymp. Sig. (2-tailed) untuk variabel aktivitas fisik, daya tahan kardiorespirasi, tekanan darah sistolik dan tekanan darah diastolik sebesar 0,000 yang berarti lebih kecil dari 0,05 sehingga dapat dinyatakan data yang diperoleh tidak terdistribusi normal.

Tabel 3. Hubungan Aktivitas Fisik Terhadap Daya Tahan Kardiorespirasi

\begin{tabular}{ccccccc}
\hline \multirow{2}{*}{ Aktivitas Fisik } & \multicolumn{3}{c}{ Daya Tahan Kardiorespirasi } & \multirow{2}{*}{ Total } & \multirow{2}{*}{$\mathbf{p}$} & \multirow{2}{*}{$\mathbf{r}$} \\
\cline { 2 - 5 } & Sangat Baik & Sedang & Kurang & & \\
\cline { 1 - 5 } Ringan & $1(4,0 \%)$ & $4(16,0 \%)$ & $20(80,0 \%)$ & $25(100 \%)$ & & \\
Sedang & $3(12,5 \%)$ & $12(50,0 \%)$ & $9(37,5 \%)$ & $24(100 \%)$ & \multirow{2}{*}{0,000} & 0,695 \\
Tinggi & $25(71,4 \%)$ & $7(20,0 \%)$ & $3(8,6 \%)$ & $35(100 \%)$ & & \\
\hline Total & $29(34,5 \%)$ & $32(38,1 \%)$ & $23(27,4 \%)$ & $84(100 \%)$ & & \\
\hline
\end{tabular}

Tabel 3 menunjukkan hasil penelitian setelah dilakukan uji Spearman's Rho Test mendapatkan nilai $\mathrm{p}$ sebesar 0,000 sehingga $p<0,05$ dan nilai $r$ atau koefisien korelasi sebesar ,695 dimana hal tersebut menunjukkan bahwa ada hubungan yang signifikan dan bermakna positif antara aktivitas fisik dengan daya tahan kardiorespirasi pada pria usia dewasa akhir di wilayah Puskesmas III Denpasar Utara. Hal ini berarti bahwa hubungan antara aktivitas fisik terhadap daya tahan kardiorespirasi kuat, signifikan dan searah pada pria dewasa akhir di Denpasar Utara dimana artinya semakin tinggi aktivitas fisik maka semakin tinggi juga daya tahan kardiorespirasi.

Tabel 4. Hubungan Aktivitas Fisik Terhadap Tekanan Darah Sistolik

\begin{tabular}{|c|c|c|c|c|c|c|c|}
\hline \multirow[b]{2}{*}{ Aktivitas Fisik } & \multicolumn{4}{|c|}{ Tekanan Darah Sistolik } & \multirow{2}{*}{ Total } & \multirow[b]{2}{*}{$\mathbf{p}$} & \\
\hline & Normal & Pre hipertensi & Hipertensi 1 & Hipertensi 2 & & & \\
\hline Ringan & $2(8,0 \%)$ & $8(32,0 \%)$ & $8(32,0 \%)$ & $7(28,0 \%)$ & $25(100 \%)$ & & \\
\hline Sedang & $7(29,2 \%)$ & $4(16,7 \%)$ & $5(20,8 \%)$ & $8(33,3 \%)$ & $24(100 \%)$ & & \\
\hline Tinggi & $15(42,9 \%)$ & $7(20,0 \%)$ & $7(20,0 \%)$ & $6(17,1 \%)$ & $35(100 \%)$ & 4 & \\
\hline Total & $24(28,6 \%)$ & $19(22,6 \%)$ & $20(23,8 \%)$ & $21(25,0 \%)$ & $84(100 \%)$ & & \\
\hline
\end{tabular}

Tabel 4 menunjukkan hasil penelitian setelah dilakukan uji Spearman's Rho Test mendapatkan nilai p sebesar 0,074 sehingga $p>0,05$ dan nilai $r$ atau koefisien korelasi sebesar -,196. Berdasarkan uji statistik dapat ditemukan 
bahwa tidak ada hubungan yang signifikan antara aktvitas fisik terhadap tekanan darah sistolik pada pria dewasa akhir di wilayah Puskesmas III Denpasar Utara.

Tabel 5. Hubungan Aktivitas Fisik Terhadap Tekanan Darah Diastolik

\begin{tabular}{cccccccc}
\hline \multirow{2}{*}{ Aktivitas Fisik } & Normal & Pre hipertensi & Hipertensi 1 & Hipertensi 2 & \multirow{2}{*}{ Total } & p & r \\
\cline { 2 - 5 } & $6(24,0 \%)$ & $9(36,0 \%)$ & $5(20,0 \%)$ & $5(20,0 \%)$ & $25(100 \%)$ & & \\
\cline { 1 - 6 } Sedang & $7(29,2 \%)$ & $5(20,8 \%)$ & $6(25,0 \%)$ & $6(25,0 \%)$ & $24(100 \%)$ & \multirow{2}{*}{0,848} & 0,021 \\
Tinggi & $9(25,7 \%)$ & $10(28,6 \%)$ & $8(22,9 \%)$ & $8(22,9 \%)$ & $35(100 \%)$ & & \\
\hline Total & $22(26,2 \%)$ & $24(28,6 \%)$ & $19(22,6 \%)$ & $19(22,6 \%)$ & $84(100 \%)$ & & \\
\hline
\end{tabular}

Tabel 5 menunjukkan hasil penelitian setelah dilakukan uji Spearman's Rho Test mendapatkan nilai p sebesar 0,848 sehingga $p>0,05$ dan nilai $r$ atau koefisien korelasi sebesar, 021 . Berdasarkan uji statistik dapat ditemukan bahwa tidak ada hubungan yang signifikan antara aktvitas fisik terhadap tekanan darah diastolik pada pria dewasa akhir di wilayah Puskesmas III Denpasar Utara.

\section{DISKUSI \\ Karakteristik Sampel}

Penelitian ini telah dilakukan terhadap 84 orang pria yang telah memenuhi kriteria inklusi dan eksklusi sebagai sampel yang terdapat di wilayah Puskesmas III Denpasar Utara. Sampel dalam penelitian ini memiliki rentang usia yaitu 36-45 tahun (usia dewasa akhir). Hasil dari penelitian menunjukkan kategori usia 40 tahun merupakan kategori tertinggi yaitu sebanyak 16 orang $(19,0 \%)$ sedangkan kategori usia 44 tahun merupakan ketegori terendah yaitu sebanyak 3 orang $(3,6 \%)$. Semakin bertambahnya usia akan menyebabkan terjadinya penurunan kapasitas fungsional tubuh yang menyebabkan keterbatasan dalam melakukan aktivitas fisik. Daya tahan kardiorespirasi semakin menurun sejalan dengan bertambahnya usia seseorang, dengan penurunan $8-10 \%$ perdekade untuk seseorang yang tidak aktif, sedangkan pada seseorang yang aktif penurunan tersebut menjadi $4-5 \%$ perdekade. ${ }^{4}$ Terjadinya peningkatan usia maka terjadilah proses-proses degeneratif pada semua organ tubuh termasuk jantung dan pembuluh darah yang akan menyebabkan peningkatan tekanan darah oleh karena perubahan fisiologis.

Jenis kelamin merupakan salah satu faktor yang mempengarui tingkat daya tahan kardiorespirasi seseorang. Pria dan wanita memiliki kebugaran jasmani yang berbeda hal ini berkaitan dengan daya tahan seseorang. sampai umur pubertas tidak terdapat perbedaan daya tahan kardiorespirasi laki-laki dan wanita, setelah umur tersebut secara fisiologi nilai pada wanita lebih rendah sampai $15 \%$ daripada pria. Perbedaan terjadi setelah massa pubertas yang disebabkan oleh adanya perbedaan maximal muscular power yang berhubungan dengan luas permukaan tubuh, komposisi tubuh, jumlah hemoglobin, kapasitas paru dan sebagainya. Tetapi ada faktor lain yang dapat mempengaruhi peningkatan daya tahan kardiorespirasi salah satunya adalah aktivitas fisik. ${ }^{5}$

Pria memiliki kemungkinan lebih tinggi terkena tekanan darah tinggi dibandingkan wanita sebelum umur 45 tahun. Sedangkan wanita lebih mungkin mengidap tekanan darah tinggi dibandingkan pria setelah umur 64 tahun. Hal ini dikarenakan hormon esterogen pada wanita dapat membantu mencegah terjadinya arteriskeloris yang menyebabkan hipertensi. Saat wanita menopause maka hormon esterogen juga akan berkurang sehingga wanita akan cenderung mengalami hipertensi. ${ }^{6}$

Penelitian yang dilakukan pada 84 sampel pria menghasilkan data tertinggi yaitu pada aktivitas fisik tinggi sebanyak 35 orang $(41,7 \%)$, data terendah yaitu pada aktivitas fisik sedang sebanyak 24 orang $(28,6 \%)$ dan aktivitas fisik ringan sebanyak 25 orang $(29,8 \%)$. Aktivitas fisik merupakan gerakan tubuh yang dihasilkan oleh otot rangka yang memperlukan energi seperti saat bekerja, bermain atau melakukan pekerjaan rumah tangga. Aktivitas fisik merupakan faktor penunjang kesehatan seseorang, salah satunya dapat meningkatkan daya tahan kardiorespirasi. Seseorang dengan aktivitas fisik yang sedang atau tinggi maka akan memiliki daya tahan kardiorespirasi yang baik.

Saat melakukan aktivitas fisik yang cukup tinggi maka kebutuhan oksigen juga akan meningkat dan begitu sebaliknya. Sehingga terjadi pengaturan perbaikan pernafasan yang menyebabkan kardiorespirasi menjadi lebih baik. Perbaikan ini terjadi karena respon tubuh terhadap aktivitas fisik merupakan hasil respon koordinasi dari sistem organ, termasuk jantung, paru, pembuluh darah dan otot. Aktivitas fisik akan menyebabkan kontraksi pada otot-otot tubuh yang dimana memerlukaan energi berupa oksigen dalam pergerakannya. Dalam hal ini paru akan bekerja secara aktif meningkatkan pertukaran gas oksigen dan karbondioksida. Oksigen yang masuk akan menembus membran alveoli yang nantinya akan diikat oleh hemoglobin dan dibawa ke jantung. Jadi, semakin banyak masa otot yang terlibat dalam aktivitas fisik maka semakin banyak kebutuhan oksigen yang dibutuhkan sebagai energi. Hal ini menyebabkan peningkatan pada VO2maks seseorang sehingga menjadikan daya tahan kardiorespirasi menjadi lebih baik.

Aktivitas fisik juga salah satu faktor yang dapat mempengaruhi tekanan darah. Seseorang yang memiliki aktivitas fisik yang teratur menyebabkan terjadinya perubahan misalnya otot polos jantung akan bertambah kuat sehingga daya tampung besar dan konstruksi atau denyutnya kuat dan teratur, selain itu elastisitas pada pembuluh darah juga akan bertambah karena adanya rileksasi dan vasodilatasi sehingga timbunan lemak akan berkurang dan meningkatkan kontraksi otot dinding pembuluh darah. Tetapi saat terdapat timbunan lemak pada pembuluh darah dan tidak terjadi vasodilatasi maka tekanan darah akan meningkat sehingga akan menyebabkan seseorang mengalami hipertensi. $^{7}$

\section{Hubungan Aktivitas Fisik Terhadap Daya Tahan Kardiorespirasi}

Hubungan aktivitas fisik terhadap daya tahan kardiorespirasi pada penelitian ini dapat diketahui dengan menggunakan uji analisis Spearman's Rho Test yang tertera pada tabel 3. Hasil pada tabel tersebut menyatakan bahwa nilai $p$ sebesar 0,000 sehingga $p<0,05$ dan nilai $r$ atau koefisien korelasi sebesar ,695 dimana hal tersebut menunjukkan 
bahwa ada hubungan yang signifikan dan bermakna positif antara aktivitas fisik dengan daya tahan kardiorespirasi pada pria usia dewasa akhir di wilayah Puskesmas III Denpasar Utara. Hal ini berarti bahwa hubungan antara aktivitas fisik terhadap daya tahan kardiorespirasi kuat, signifikan dan searah pada pria dewasa akhir di Denpasar Utara dimana artinya semakin tinggi aktivitas fisik maka semakin tinggi juga daya tahan kardiorespirasi.

Hasil dari aktivitas fisik 84 orang sampel pria yang telah diteliti dan dianalisa menunjukkan bahwa sebagian besar pria dewasa akhir yang berada di Wilayah Puskesmas III Denpasar Utara memiliki aktivitas fisik yang tinggi. Hal ini dikarenakan usia mereka yang masih tergolong produktif untuk dapat melakukan banyak aktivitas termasuk dalam pekerjaan.

Hasil dari sebuah penelitian menyatakan bahwa terdapat hubungan yang signifikan antara aktivitas fisik terhadap peningkatan VO2max. ${ }^{8}$ Ini diperkuat lagi dengan penelitian yang dilakukan terhadap mahasiswa Fakultas Kedokteran dengan mahasiswa D1 bea cukai. Didapatkan hasil bahwa mahasiswa Fakultas Kedokteran memiliki daya tahan kardiorespirasi yang lebih rendah dibandingkan D1 bea cukai. Hal ini dikarenakan aktivitas fisik mahasiswa FK lebih rendah dibandingkan aktivitas fisik D1 bea cukai yang rata-rata rutin olahraga setiap minggunya. ${ }^{9}$

Beraktivitas fisik secara rutin dan teratur dapat memicu seluruh organ untuk menjalankan fungsinya sehingga mampu beradaptasi terhadap setiap beban yang diberikan. Aktivitas fisik yang tinggi akan menyebabkan peningkatan energi yang dibutuhkan tubuh dan juga otot dalam pergerakannya hal ini dapat mempengaruhi otot untuk menjadi lebih kuat. Perubahan fungsi otot yang lebih baik, terutama otot pernafasan menyebabkan pernafasan lebih efisien pada saat istirahat.

Ventilasi paru pada seseorang yang rutin melakukan aktivitas fisik secara baik akan memiliki pernafasan lebih lambat dan lebih dalam. Pada seseorang yang terlatih melakukan aktivitas fisik sedang hingga tinggi maka kebutuhan energi seperti oksigen dalam tubuh juga akan meningkat sehingga akan terjadi pengaturan perbaikan pernafasan yang menyebabkan peningkatan daya tahan kardiorespirasi. Hal ini terjadi karena respon tubuh terhadap aktivitas fisik merupakan hasil respon koordinasi dari sistem organ, termasuk jantung, paru, pembuluh darah dan otot. Semakin banyak masa otot yang terlibat dalam aktivitas fisik maka semakin besar kontribusi pompa otot pada vena. Hal ini menyebabkan peningkatan pada curah jantung yang membawa darah kaya akan oksigen kesekuruh tubuh dan menjadikan daya tahan kardiorespirasi menjadi lebih baik.

\section{Hubungan Aktivitas Fisik Terhadap Tekanan Darah}

Hubungan aktivitas fisik terhadap tekanan darah sistolik pada penelitian ini diketahui dengan menggunakan uji analisis Spearman's Rho Test yang tertera pada tabel 4. Hasil pada tabel tersebut menyatakan bahwa p sebesar 0,074 sehingga $p>0,05$ dan nilai $r$ atau koefisien korelasi sebesar -,196. Berdasarkan uji statistik dapat ditemukan bahwa tidak ada hubungan yang signifikan antara aktvitas fisik terhadap tekanan darah sistolik pada pria dewasa akhir di wilayah Puskesmas III Denpasar Utara.

Hubungan aktivitas fisik terhadap tekanan darah diastolik pada penelitian ini diketahui dengan menggunakan uji analisis Spearman's Rho Test yang tertera pada tabel 5. Hasil pada tabel tersebut menyatakan bahwa p sebesar 0,848 sehingga $p>0,05$ dan nilai $r$ atau koefisien korelasi sebesar ,021. Berdasarkan uji statistik dapat ditemukan bahwa tidak ada hubungan yang signifikan antara aktvitas fisik terhadap tekanan darah diastolik pada pria dewasa akhir di wilayah Puskesmas III Denpasar Utara.

Berdasarkan penelitian yang telah dilakukan didapatkan hasil bahwa tidak terdapat hubungan antara aktivitas fisik terhadap tekanan darah sistolik dan tekanan darah diastolik. ${ }^{10}$ Hasil uji statistik dengan menggunakan Rank Spearman diperoleh $p$ sebesar 0,538 ( $p>0,05)$ pada tekanan darah sistolik. Hasil uji statistik dengan Rank Spearman diperoleh $p$ sebesar 0,321 ( $p>0,05)$ pada tekanan darah diastolik. Tidak terdapat hubungan aktivitas fisik terhadap tekanan darah sistolik dan diastolik. Hal ini dikarenakan status gizi pada sampel penelitian yang cenderung tidak baik dan memiliki resiko peningkatan pada tekanan darah.

Hasil dari sebuah penelitian menggunakan uji Pearson Correlation di dapatkan nilai p sebesar 0,947 (p>0,05) Ho diterima pada tekanan darah sistolik yang berarti tidak ada hubungan aktivitas terhadap tekanan darah sistolik. Didapatkan $p$ sebesar 0,745 ( $p>0,05)$ Ho diterima pada tekanan darah diastolik yang berarti tidak ada hubungan antara aktivitas fisik terhadap tekanan darah diastolik. Penelitian ini dapat disimpulkan bahwa tidak ada hubungan aktivitas fisik terhadap tekanan darah di kelurahan Sondokan, Surakarta pada pria dan wanita. Hal ini dikarenakan dari hasil wawancara aktivitas fisik masih ada beberapa subjek yang tidak terbuka sewaktu diwawancarai karena suasana tidak kondusif. Selain itu juga dikarenakan status gizi sampel pria dan wanita juga penurunan hormon esterogen pada beberapa sampel wanita. ${ }^{11}$

Beberapa penelitian juga mengungkapkan hasil yang serupa pada pasien pria dan wanita dengan rentang usia 20-50 tahun di Puskesmas I Yogyakarta dengan $p$ sebesar 0,651 ( $p>0,05)$ yang diartikan bahwa tidak ada hubungan aktivitas fisik terhadap tekanan darah. Seseorang dengan aktivitas fisik dengan baik secara rutin seperti berolahraga dan aerobik secara teratur maka dapat menurunkan tekanan darah. Didapatkan hasil $p$ sebesar 0,483 ( $p>0,05)$ yang berarti tidak ada hubungan aktivitas fisik terhadap tekanan darah yang dilakukan pada usia dewasa di wilayah Puskesmas Surakarta. Hal ini disebabkan karena beberpa faktor yang tidak dikontrol peneliti seberti pola hidup yang tidak baik yaitu merokok, makanan berlemak dan konsumsi kafein.

Hasil uji analisis Spearman's Rho Test yang menyatakan bahwa tidak ada hubungan aktivitas fisik terhadap tekanan darah sistolik dan diastolik. Hal ini disebabkan oleh karena terdapat beberapa mekanisme yang berperan dalam sistem kardiovaskular selama aktivitas fisik yang akan mempengaruhi tekanan darah yaitu : mekanik, metabolik, dan hormonal. Jika seseorang tiba-tiba berolahraga seperti berlari maka curah jantungnya akan meningkat sebelum mekanisme metabolik dan hurmonalnya diaktifkan. Peningkatan awal curah jantung dihasilkan dari sistem kerja otot rangka yang meningkatkan aliran balik vena dan curah jantung. Beberapa detik setelah kontraksi otot dimulai, 
mekanisme metabolik di dalam otot yang berkontraksi menyebabkan dilatasi pada pembuluh darah dan meningkatkan aliran darah.

Mekanisme humoral merupakan salah satu faktor yang dapat mempengaruhi tekanan darah yang dimana . Faktor humoral dapat mempengaruhi jantung dan pembuluh darah yang secara tidak langsung juga mempengaruhi kardiovaskular melalui perubahan volume darah yang nantinya akan berpengaruh pada tekanan darah. Faktor humoral utama meliputi katekolamin dalam darah, sistem renin angiotensin aldosteron, peptida natriuretik atrium dn hormon antidiuretik. Terdapat hormon lain juga sepeti tiroksin, estrogen dan insulin. Pengaruh humoral diperlukan untuk mempertahankan tekanan darah arteri agar tetap normal dalam berbagai keadaan fungsi tubuh seseorang. Mekanisme humoral memungkinkan tubuh untuk menyesuaikan diri dengan perubahan sikap tubuh, aktivitas fisik atau kondisi lingkungan.

Mekanisme humoral pada setiap orang memiliki respon yang tidak sama, seseorang dengan mekanisme humoral yang terganggu akan mempengaruhi tekanan darahnya dalam berbagai keaadan fungsi tubuh. Hal ini dikarenakan mekanisme humoral bekerja melalui perubahan resistansi pembuluh sistemik, komplians vena, volume darah dan fungsi jantung, melalui sistem ini tekanan arteri dapat diatur dengan efektif. Sampel pada penelitian ini tentu tidak memiliki mekanisme kerja humoral yang sama semua. Pada sampel yang memiliki sistem mekanisme yang kurang baik tentu akan mempengaruhi tekanan darahnya. Hal ini juga merupakan salah satu faktor yang tidak dapat di kontrol oleh peneliti sehingga tidak terdapatnya hubungan dari aktivitas fisik yang dilakukan terhadap tekanan darah.

Perubahan kardiovaskular yang terjadi selama aktivitas fisik dipengaruhi oleh banyak faktor yang dalam mengubah respon fisiologis tubuh. Suhu dan kelembapan yang tinggi mempengaruhi respon kardiovaskular yang nantinya berpengaruh terhadap tekanan darah. Suhu dan kelembapan yang tinggi selama beraktivitas dapat mengalirkan fraksi curah jantung yang lebih banyak ke kulit untuk meningkatkan pengeluaran panas. Hal ini akan menurunkan ketersediaan aliran darah untuk otot yang berkontraksi. Dengan peningkatan suhu dan kelembapan, curah jantung dan konsumsi oksigen maksimal dicapai pada beban yang lebih kecil, sehingga mengurangi kemampuan kerja otot dan ketahanannya. Seseorang akan lebih mudah dehidrasi yang menyebabkan volume darah turun, dan ini mengurangi peningkatan curah jantung yang normal.

Pada penelitian ini tidak semua sampel melakukan aktivitas fisik dalam suhu dan kelembapan yang sama setiap harinya. Seperti, sampel dengan pekerjaan pegawai kantoran berada pada suhu dan kelembapan yang berbeda pada sampel dengan pekerjaan buruh tukang setiap harinya. Hal ini juga merupakan salah satu faktor yang tidak dapat di kontrol oleh peneliti sehingga tidak terdapatnya hubungan dari aktivitas fisik yang dilakukan terhadap tekanan darah. Peneliti tidak mampu menggolongkan aktivitas fisik sehari-hari sampel berdasarkan suhu dan kelembapan di lingkungan sekitarnya.

\section{SIMPULAN}

Terdapat hubungan yang signifikan dengan arah positif antara aktivitas fisik terhadap daya tahan kardiorespirasi pada pria dewasa akhir dengan rentang usia 36-45 tahun di wilayah Puskesmas III Denpasar Utara. Semakin tinggi aktivitas fisik maka semakin tinggi juga daya tahan kardiorespirasi. Tetapi, tidak terdapat hubungan yang signifikan antara aktivitas fisik terhadap tekanan darah pada pria dewasa akhir dengan rentang usia 36-45 tahun di wilayah Puskesmas III Denpasar Utara.

\section{DAFTAR PUSTAKA}

1. Hapsari, A. N. 2016. 'Hubungan Asupan Lemak Dan Aktivitas Fisik Dengan Tekanan Darah Pada Lansia Di Kelurahan Sondakan Surakarta'.

2. Mutiarawati, R. 2009. 'Hubungan Antara Riwayat Aktivitas Fisik Dengan Kejadian Hipertensi Pada Usia 45-54 Tahun Study Di Wilayah Kelurahan Tlogosari Kulon Semarang Tahun 2009'.

3. Novandaru. 2016. 'Tingkat Daya Tahan Kardiorespirasi Peserta Ekstrakurikuler Bola Basket Danfutsal Tahun Ajaran 2015/2016 Di Sma N 1 Temon Kulon Progo Daerah Istimewa Yogyakarta', P. 2016.

4. Novitaningtyas, T. 2014. 'Hubungan Karakteristik (Umur, Jenis Kelamin, Tingkat Pendidikan) Dan Aktivitas Fisik Dengan Tekanan Darah Pada Lansia Di Kelurahan Makamhaji Kecamatan Kartasura Kabupaten Sukoharjo'.

5. Purnomo. 2010. 'Pengukuran Tekanan Darah Digital Dengan Database', Pp. 5-28.

6. Prasetyo, D. A. 2015 'Faktor-Faktor Yang Berhubungan Dengan Kejadian Hipertensi Pada Usia Dewasa Muda Di Wilayah Puskesmas Sibela Surakarta'.

7. Riskesdas. 2013. 'Riset Kesehatan Dasar', 6. Doi: 1 Desember 2013.

8. Suharjana. 2009. 'Tingkat Kebugaran Kardiorespirasi Guru Sdit^ Luqman Al Hakim Yogyakart', Pp. $201-211$.

9. Teju. 2018. 'Pengaruh Latihan Fisik Terhadap Peningkatan Vo2 Max Pada Remaja Putri Universitas 'Aisyiyah Yogyakarta Naskah Publikasi', Pp. 1-12.

10. Wulandari, S. P. 2013. 'Perbandingan Daya Tahan Kardiorespirasi Mahasiswa Program Studi Pendidikan Dokter Fakultas Kedokteran Universitas Udayana Angkatan 2013 Dengan Mahasiswa D1 Bea Cukai Sekolah Tinggi Akutansi Negara Denpasar Angkatan 2013'.

11. WHO. 2008. 'Who Report On The Global Tobacco Epidemic.Who. Available From: Http://Www.Who.Int/Tobacco/Mpower/Mpower_Report_Full 2008.Pdf. (Diakses Pada 05 Januari 2019)'.

12. Yuliyanato, B. 2013 Hubungan Daya Tahan Kardiorespirasi Dan Pendidikan Orang Tua Terhadap Prestasi Belajar Penjas Siswa Sma Negeri 1 Kasihan Bantul Yang Mengikuti Ektrakurikuler Sepak Bola Skripsi. 